Uşak Üniversitesi Sosyal Bilimler Dergisi

$2015,8 / 1$

\title{
Öğretmen Adaylarının Alan Deneyimleri Sürecinin Etkililiğinin Artırılmasında Çevrimiçi Öğrenme Ortamının Rolü
}

Hüseyin ÖZÇINAR*

\begin{abstract}
Özet
$\mathrm{Bu}$ çalışmanın amacı, geliştirilen çevrimiçi öğrenme ortamının öğretmen adaylarının alan deneyimi sürecinde akran ve sürecin diğer paydaşlarıyla etkileşiminin artırılması ve derinleştirilmesine katkı sağlayıp sağlamadığının belirlenmesidir. Araştırmada ayrıca çevrimiçi öğrenme ortamıyla desteklenen alan deneyimlerinin öğretmen adaylarının yansıtıcı düşünme düzeyini artırıp artırmadığının belirlenmesi amaçlanmaktadır. Karışık desenli durum yönteminin kullanıldığı araştırmanın katılımcılarını Pamukkale Üniversitesi Eğitim Fakültesi Sınıf Öğretmenliği Bölümünde Öğretmenlik Uygulaması dersini alan $17 \mathrm{k} 1 \mathrm{z} 14$ erkek toplam 31 lisans öğrencisi oluşturmuştur. Araştırma sonucunda, çevrimiçi öğrenme ortamının öğretmen adayları tarafından yansıtıcı düşünmeyi desteklemek için bir araç olmasının ötesinde süreçte yaşanan sorunlarla ilgili destek almak, bilgi toplamak ve farklı görüşlerden haberdar olmaya olanak sağlayan bir iletişim ortamı olarak algılandığı görülmüştür. Öğretmen adayları, mesaj başlatıcıları mesajların tartışmacılık düzeyini artıran ancak daha fazla zaman ve çaba harcanmasına neden olan yapılandırma araçları olarak algılanmışlardır. Araştırmada elde edilen bir diğer bulgu, çevrimiçi öğrenme ortamı ile desteklenen alan deneyimi sürecinde öğretmen adaylarının çevrimiçi tartışmalarındaki yansıtıcılık düzeylerinin istatistiksel olarak anlamlı artış gösterdiğidir.

Anahtar Kelimeler: Öğretmen Adaylarının Alan deneyimleri, Çevrimiçi Öğrenme Ortamı, Mesaj Başlatıcılar, Yapılandırılmış Mesaj Oluşturma.
\end{abstract}

\section{The Role of Online Learning Environment in Increasing Effectiveness of Student Teachers' Field Experiences}

\begin{abstract}
This study is aimed to detect whether or not online learning environment, which was developed for this study, make contributions to
\end{abstract}

*Yrd. Doç. Dr., Pamukkale Üniversitesi Eğitim Fakültesi 
increase and deepen the interaction between pre-service teachers' peers and other companions in their field experience process. In addition, this study is also aimed to detect whether or not online learning environment supported field experience increase pre-service teachers' levels of reflective thinking. Participants of the research are composed of 31 license (17 female and 14 male) students who receive education in Pamukkale University Faculty of Education, department of primary education and take teaching practice course. As a result of the research it is seen that pre-service students perceive online learning environment, beyond a tool to support reflective thinking, as a communication environment which enable them receive support about possible problems of the process, obtain data, and realize different perspectives. It is also seen that pre-service teachers' reflective thinking levels statistically increased within online discussions during the process of online learning environment supported field experience.

Key Words: Field Experiences of Teacher Candidates, Online Learning Environment, Message Starters, Structured Message Form.

\section{Giriş}

Araştırmalar göstermektedir ki, öğretmen adayları öğretim uygulamalarını, programın diğer tüm bileşenlerinden daha önemli bulmaktadırlar (Anderson, 1997; Akt. Bencze, Hewitt ve Pedretti, 2001, Tang, 2003).Birçok ülkede, öğretmen yetiştirme programlarında öğretim uygulamalarının gözlemlenmesi ve doğrudan deneyimlenmesine olanak sağlayan derslere programda daha çok yer verilmesi için çaba harcanmaktadır (Barone, Berliner, Blanchard, Casanova ve McGowan, 1996). Ülkemizde de üniversiteler öğretmenlik eğitimi alan öğrencilere 'Okul Deneyimi' ve 'Öğretmenlik Uygulaması' adı altında çeşitli derslerde, öğretimi gözlemleme ve deneyimleme olanağı sunmaktadırlar.

Öğretmen yetiştirme programlarında 7 . ve 8 . dönemde yer alan “Okul Deneyimi" ve 'Öğretmenlik Uygulaması' dersleri YÖK-Dünya Bankası Milli Eğitimi Geliştirme Projesi Hizmet Öncesi Öğretmen Eğitimi çerçevesinde; öğretmen adaylarının kazanmış olduğu bilgi ve becerilerini bir okul ortamında deneyimleyip geliştirebilmesi ve mesleğinin gerektirdiği özellikleri kazanabilmesi için planlanan bir derstir (YÖK, 1998). Bu ders aracılığıyla öğretmen adaylarından gerçek okul ortamında gözlem yapmaları ve öğretimi deneyimlemeleri beklenmektedir. Ancak öğretmen adaylarına öğretimi gözlemleme ve deneyimleme olanağı sunulan bu uygulamalarla ilgili alanyazında farklı sorunlardan bahsedilmektedir. Öğretmen adayları, uygulama öğretmeni ve uygulama öğretim üyesi 
arasındaki etkileşimin nitelik ve nicelik olarak yetersizliği (Gökçe ve Demirhan, 2005; Özbek ve Aytekin, 2003; Yıldız, 2002), öğretmen adaylarının sınıf gözlemlerinin yüzeyselliği ve belirli konularla sınırlı kalması (Lampert ve Ball, 1998) bu sorunlardan bazılarıdır.

Öğretmen adayları ve uygulama öğretim üyesi ve öğretmeni arasındaki etkileşim çoğu zaman sorunlu ya da dağınıktır (Borko ve Mayfield, 1995). Türkiye de öğretim üyelerinin ders yükü oldukça fazladır bunun yanı sıra "Okul Deneyimi" ve "Öğretmenlik Uygulaması" derslerinde öğretim üyelerine genellikle 15 ya da daha fazla öğretmen adayının alan deneyimleri sürecine rehberlik etme görevi verilmektedir. Bu durum öğretim üyelerinin öğretmen adaylarını yeterince gözlemleyememesine, ders sonrası çözümlemelerin yüzeysel olmasına (Paker, 2005) ya da bilişsel derinlikten yoksun, duygusal destekle sinırlı kalmasına neden olmaktadır (Abell,Dillon, Hopkins, McInerney ve O'Brien, 1995; Arredondo ve Rucinski, 1998). Böyle bir çözümleme ya da tartışma süreci öğretmen adaylarını uygulamalarını, öğretimle ilgili varolan inançlarını sorgulamaya ve yansıtıcı düşünmeye özendirmek yerine sözde bir uzlaşmayla sonuçlanmaktadır (Borko ve Mayfield, 1995). Paker (2005), yaptığ1 araştırmada öğretmen adaylarının öğretim üyelerinden öğretim uygulamalarının planlanması aşamasında da yeterli desteği alamadıklarını be bu durumun öğretmen adaylarında "travma"ya neden olduğunu ortaya koymuştur.

Benzer bir sıkıntı öğretmen adaylarının uygulama öğretmeniyle etkileşiminde de ortaya çıkmaktadır. Ülkemizde öğretim uygulaması dersinde uygulama okulundaki her sınıfa en az altı öğretmen adayı gönderilmektedir. Altı öğretmen adayının aynı sınıfta yer almasının sınıf iklimini değiştirebileceği gibi öğretmen adaylarının uygulama öğretmeniyle etkileşiminin kalitesini de etkileyeceği düşünülebilir. Kiraz (2002), Özbek ve Aytekin (2003) ve Paker (2005) yaptıkları araştırmalarda öğretmen adaylarının uygulama öğretmeninden yeterince rehberlik ve yardım alamadıklarını ve etkili iletişim kuramadıklarını ortaya koymuşlardır.

Son yıllarda bilgi ve iletişim teknolojilerindeki gelişmeler, bilgisayar ağlarının eğitim ortamlarındaki kullanımını yaygınlaştırmaya başlamıştır (Hew, Cheung ve Ling, 2009; Wang, 2008; Yamada, 2009). Bu durum, eğitim uygulamalarını sınıfın fiziksel sınırlarının ötesine taşıyarak öğrenci-öğrenci ve öğrenci-öğretmen arasındaki iletişimin sağlanmasında "Bilgisayar Aracılı İletişim"i (BAI) (computer-mediated communication-CMC) başka bir deyişle "çevrimiçi iletişim" $i$ eğitimin bir parçası haline getirmiştir (De Wever, Schellens, Valcke ve Van Keer, 2006). Bunun sonucunda öğrenciler, ders öğretmenleri ve akranları ile gerek eşzamanlı (synchronous) gerekse 
eşzamansız (asynchronous) bilgisayar aracılı iletişim araçlarını kullanarak etkileşim kurmaya, çevrimiçi öğrenme ortamlarında tartışmaya ve bu ortamlarda öğrenmeye başlamışlardır (Lapadat, 2002; Romiszowski ve Mason, 2004; Wang, 2008). Zamandan ve mekandan bağımsız olarak etkileşim olanağı sunan çevrimiçi öğrenme ortamlarının öğretmen adayları ile uygulama öğretim üyesi ve öğretmeni arasındaki etkileşim sorunlarının giderilmesinde önemli bir katkı sağlaması olasıdır.

Öğrencilere yalnızca birebir değil, çok kişi ile etkileşim kurma ve çevrimiçi öğrenme toplulukları oluşturma olanağı sunan çevrimiçi öğrenme ortamları, yüz yüze ortamlarda çekingen, güdülenmesi düşük ya da başarısız olan öğrencilere de tartışmalara katılmak için fırsat eşitliği sağlayarak, bu öğrencilerin öğretmenle iletişim kurma ve derse etkin katılım olasılıklarını arttırmaktadır (Warschauer, 1997, akt. Yodkamlue, 2008; Yamada, 2009). Bu durum, öğrencilerin çevrimiçi tartışmaları yüz yüze ortamlara göre daha demokratik ve derse katılım için daha çok fırsat eşitliği sunan bir ortam olarak algılamalarını sağlamaktadır (Levin, Kim ve Riel, 1990, akt. Swan, 2002). Dahası etkileşimli bir ortam olan çevrimiçi tartışmaların, yansıtma ve yazma için zaman ve kişisel gizlilik sağlayan doğası, bireyin içe dönüşünü, yansıtıcılığını ve iç sesinin gelişimini desteklemektedir. Bu durum, öğrencilerin çevrimiçi ortamlarda kendilerini daha özgür hissetmelerini sağlamaktadır. Ayrıca çevrimiçi iletişimde yüz ve benzeri bireysel özelliklerin daha az ortaya çıkması, yüz yüze iletişimde katılım sorunu yaşayan kişilerin, çevrimiçi iletişimde daha çok yer alması için olanak sağlamaktadır. Bunun yanı sıra çevrimiçi iletişimde otoriter seslerin baskısı da daha az hissedilmektedir (Pincas,1995). Bu etkenler, çevrimiçi iletişimi, katılımın artması ve düşüncelerin açılıkla dile getirilmesi için uygun bir ortam haline getirmektedir.

Alan deneyimi sürecinde görev yapan uygulama öğretim üyelerinin öğretmen adaylarının sınıfta ne gözledikleri ile ilgili kontrolü oldukça sınırlıdır. Bu durum gözlemlerden edinilen sonuçların oldukça bireysel olmasına ve belirli konularla sinırlı kalmasına neden olmaktadır (Lampert ve Ball,1998; Feiman-Nemser ve Buchmann,1985). Bunun yanı sıra öğretmen adayları okul deneyimlerinde süreç ve sınıf yönetimi ile ilgili konuların altında ezilmektedir (Zeichner ve Tabachnick, 1981). Böyle bir sürecin içinde yer alan öğretmen adayı öğretimle ilgili yeni yaklaşımları ve kuramsal bilgilerini uygulamaya dönüştürme konusunda isteksiz davranmakta bir başka deyişle öğrencilik yaşantılarında öğretimle ilgili edindikleri izlenimler onların öğretmen olma yolunda edindikleri bilgileri uygulamaya dönüştürmelerini engelleyici bir etki göstermektedir. Bu durum öğretmen adaylarının öğretim uygulamalarını, öğretmen yetiştirme programında 
edindikleri bilgiler ışığında sürdürmek yerine kendi öğrenciliklerinden edindikleri izlenim bilgi ve inanışlarından yola çıarak biçimlendirmelerine neden olmaktadır (Lortie,1975). Cochran-Smith ve Lytle'a göre (1993) bu durum aynı zamanda okul deneyimi için amaçlanan öğretimin sorgulama temelli bir biçimde incelenmesi sürecini sekteye uğratmaktadır.

Öğretmen adayları doğrudan sinıf gözlemlerine yönlendirildiklerinde öğretmenin nasıl göründüğü, ses tonu ve vücut dili gibi öğretimle doğrudan ilgili olmayan öğelere odaklanmakta (Fuller ve Manning, 1973, akt. Santagata, Zannoni ve Stigler, 2004) dolayısıyla öğretimi gözlemlemekte güçlük çekmektedirler. Bu nedenle, birçok öğretmen yetiştirme kurumu tarafından öğretmen adaylarına sağlanan sınıf gözlemleri, karmaşık, iyi yapılandırılmamış ve kullanışsız bir deneyime dönüşmektedir (Santagata, Zannoni ve Stigler, 2004). Dahası, okul deneyimleri öğretmen adaylarının sınırlı sayıda öğretmen ve öğrenciyi gözlemlemesine olanak tanımaktadır. Bu durum, öğretmen adaylarının karşılaştıkları örneklemin küçüklüğünü göz önüne almaksızın, gözlemlerini her duruma uygulanabilecek yaklaşımlar olarak genellemelerine neden olabilmektedir. Dolayısıyla öğretmen adaylarının okul gözlemlerinin öğretmen adaylarının farklı amaç ve gruplara uygulanabilir mesleki yargı geliştirmelerini sağlayamamaktadır (Feinam-Nemser ve Buchmann, 1985). Öğretmen adaylarının akranlarıyla ve ilgili öğretim üyeleriyle etkileşim içerisinde bulunması öğretimle ilgili daha fazla gözlemin, farklı bakış açılarından sorgulanmasına olanak sağlayabilir.

Bu çalışmanın amacı, alan deneyimi sürecini desteklemek amacıyla geliştirilen çevrimiçi öğrenme ortamının öğretmen adaylarının akran ve sürecin diğer paydaşlarıyla etkileşiminin artırılması ve derinleştirilmesine katkı sağlayıp sağlamadığının belirlenmesidir. Araştırmada ayrıca çevrimiçi öğrenme ortamıyla desteklenen alan deneyimlerinin öğretmen adaylarının yansıtıcı düşünme düzeylerini artırıp artırmadığının belirlenmesi amaçlanmaktadır.

- Öğretmen adayları alan deneyimleri sürecinde çevrimiçi öğrenme ortamını nasıl kullanmaktadırlar?

- Öğretmen adaylarının çevrimiçi öğrenme ortamına ve ortamın yapılandırılmış mesaj oluşturma ve mesaj başlatıcılar gibi bileşenlerine ilişkin görüşleri nelerdir?

- Öğretmen adaylarının uygulama gözlemlerini tartıştıkları çevrimiçi tartışma mesajları hangi konulara odaklanmaktadır? 
- Uygulama sürecinde öğretmen adaylarının sınıf gözlemlerine ilişkin yansıtıcılıklarında bir artış gözlemlenmekte midir?

\section{Yöntem}

$\mathrm{Bu}$ çalışmada öğretmen adaylarının alan deneyimleri sürecinde yaşadığı sorunların yapılandırılmış eş-zamansız çevrimiçi öğrenme ortamının etkililiği ve öğretmen adaylarının bu ortamla desteklenen alan deneyimi sürecine ilişkin görüşlerinin ortaya konulması amaçlanmıştır. Bu amacın gerçekleştirilebilmesi için araştırma yöntemi olarak karışık desenli durum yöntemi kullanılmıştır. Çevrimiçi öğrenme ortamının öğretmen adaylarının alan deneyimi sürecinde içerisindeki yeri, öğretmen adaylarının uygulama sürecindeki deneyimleri, uygulamaya ilişkin görüşleri, uygulama sürecinde öğretmen adaylarının gözlem ve deneyimlerine ilişkin yansıtıcı düşünme düzeylerindeki değişim, durum çalışması yöntemiyle incelenmiştir.

Creswell ve Clark'a (2007) göre karışık desenli durum yöntemi araştırma sorularının yanıtlanabilmesi için farklı veri toplama araçlarının kullanımına ve durumun derinlemesine anlaşılmasına olanak sağladığı için derinlemesine inceleme yapmaya uygun bir yöntemdir. Öğretmen adaylarının alan deneyimi sürecini desteklemek amacıyla bilgisayar ortamında oluşturulan çevrimiçi öğrenme ortamı, yapılandırılmış mesaj oluşturma ve mesaj başlatıcıların öğretmen adaylarının alan deneyimi sürecine katkısına yönelik öğretmen adayı görüşleri anket ve görüşme yöntemleriyle toplanmıştır.

Uygulamanın öğretmen adaylarının, uygulama gözlem ve deneyimlerini çözümleme becerilerine etkisi ise öğretmen adayları tarafından çevrimiçi tartışma ortamına gönderilen mesajların çözümlenmesiyle elde edilmiştir. Nitel ve nicel farklı veri toplama yöntem ve veri kaynakları kullanılarak araştırma bulgularının güvenilirliği sağlanmaya çalışılmıştır.

\section{Katılımcilar}

$\mathrm{Bu}$ araştırmanın katılımcılarını Pamukkale Üniversitesi Eğitim Fakültesi Sınıf Öğretmenliği Bölümünde Öğretmenlik Uygulaması dersini alan $17 \mathrm{kız} 14$ erkek toplam 31 öğretmen adayı oluşturmaktadır. Katılımcıların yaşları 21-24 arasında değişmektedir. Katılımcıların yaş ortalamaları 22,2 olup standart sapması 0.7'dir.

Çalışma grubunu oluşturan öğretmen adaylarının bilgisayar ve internet bağlantısına ulaşma olanaklarının, çevrimiçi tartışma forumuna 
katılımlarını etkileyebileceği düşünülebilir. Bu nedenle, anket sorularıyla katılımcıların bilgisayar ve internete erişme olanakları belirlenmeye çalışılmıştır. Elde edilen verilere göre, 11 katılımcı kişisel bilgisayarı/interneti olduğunu, 11 katılımcı bilgisayar ve internete internet kafe vb. yerlerde ulaşabildiklerini, 8 katılımcı ise aile ya da arkadaşlarının bilgisayar/internet'ini kullandıklarını belirtmişlerdir.

\section{Uygulama Süreci}

Bu çalışma için geliştirilen çevrimiçi öğrenme ortamı (bknz. Ek3) öncelikle araştırmacı ve yazılım geliştirme konusunda deneyimli iki kişi tarafından test 3 hafta süre ile test edilmiş ve çalışma süresince ortaya çıkabilecek aksaklıklar en aza indirgenmeye çalışılmıştır. Daha sonra öğretmenlik uygulaması dersini alan ve gönüllü olarak çalışmaya katılmak isteyen 31 öğretmen adayı belirlenmiştir. 2011-2012 Öğretim Yılı Bahar dönemi başlangıcında gerçekleştirilen toplantıda öğretmen adaylarına projenin amacı anlatılmış ve geliştirilen çevrimiçi tartışma platformu tanıtılmıştır. Daha sonra, tartışma platformuna öğretmen adaylarının kayıtları gerçekleştirilmiş ve öğretmen adaylarının, öğretmenlik uygulaması için belirlenen okullara gitmeye başladıkları ikinci haftadan sonra çevrimiçi tartışma platformu öğretmen adayları, ilgili öğretim üyeleri ve araştırmacı tarafından kullanılmaya başlanmıştır.

Katılımclar metin forumu ve mesaj başlatıcıları 8 haftalık tartışma süreci boyunca etkin olarak kullanmışlardır. Ancak, katılımcılar grafik forumun kullanımında zorlandıklarını, grafik forumunda görüşlerini paylaşabilmek için daha çok zaman ayırmak zorunda kaldıklarını, KPSS sınavı için de ciddi vakit ayırabilmek için görüşlerini metin forumu üzerinde paylaşmak istediklerini belirtmişlerdir. Bunun üzerine tartı̧̧malar metin forumlarında devam etmiştir.

\section{Çevrimiçi Öğrenme Ortamı}

$\mathrm{Bu}$ araştırma için geliştirilen çevrimiçi öğrenme ortamı (bkz Şekil 1.) öğretmen adaylarına mesajları bölerek her bir mesaj bölümüne "Bu görüşe katılıyorum", "Bu görüşe katılmıyorum", "Bence", "Ancak", "Çünkü", Bunun yanında", "Ben bu konuda kararsızım çünkü" gibi mesaj başlatıcılardan birini kullanarak başlama olanağı sunmaktadır. Öğretmen adaylarına mesajlarını oluştururken her biri mesaj başlatıcılar seçilerek başlatılan alt alta üç metin kutusu sağlanmıştır. Mesaj oluşturma ekranının bu şekilde bölümlere ayrılmasının temel nedeni öğretmen adaylarının görüşlerini dayanaklarıyla ve bu dayanaklarının sınırlarıyla birlikte derinlemesine ortaya koymaya özendirilmesidir. Öğretmen adaylarının 
görüşlerini iyi yapılandırılmış bir biçimde ortaya koymalarının sağlanması için her bir mesaj bölümünü yazarken başlangıçta bir mesaj başlatıcı seçmeleri istenmiştir.

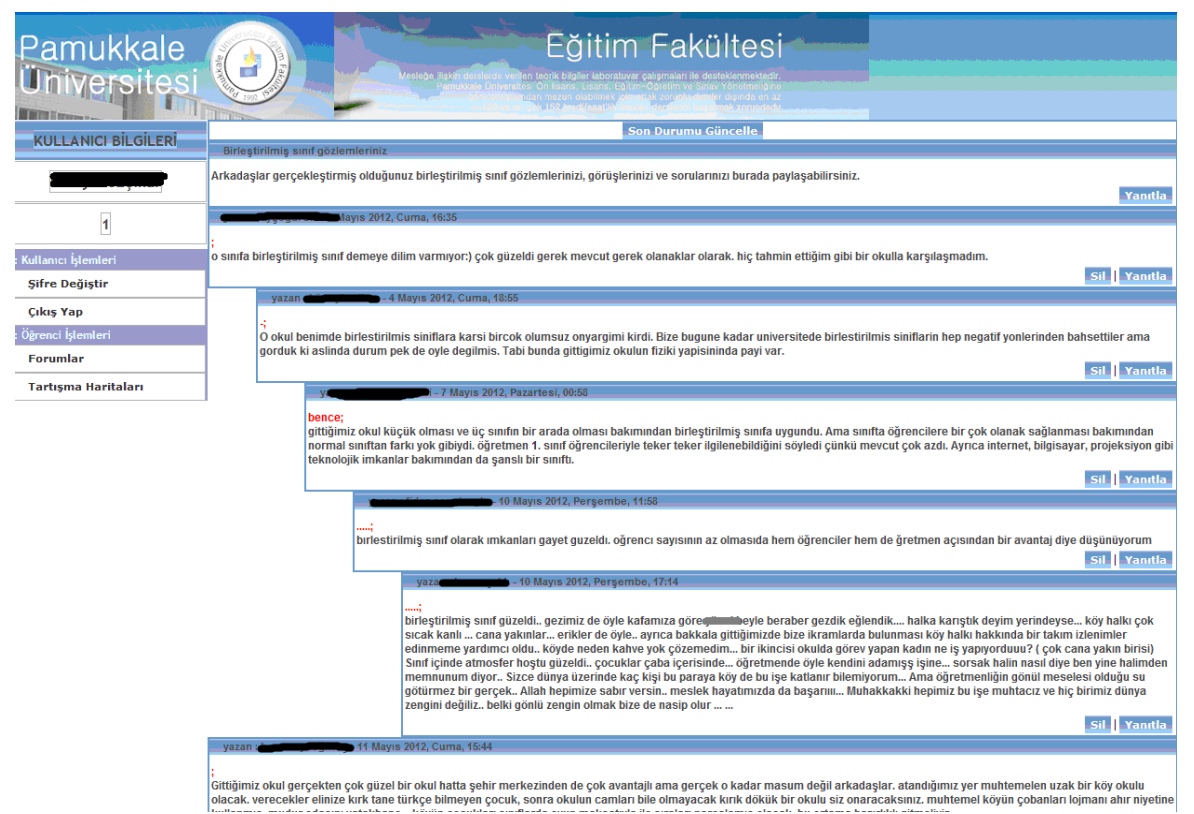

Şekil 1. Çevrimiçi öğrenme ortamı

\section{Verilerin Toplanması ve Analizi}

$\mathrm{Bu}$ çalı̧̧mada veriler tartışma forumu metni, yarı yapılandırılmış görüşmeler ve anket yoluyla toplanmıştır. Öğretmen adaylarının 8 hafta boyunca çevrimiçi tartışma forumunda paylaştıkları sınıf gözlemleri ve bu gözlemlere ilişkin tartışmalar öğretmen adaylarının yansıtıcı düşünme düzeylerinin ve tartışma içeriğinin belirlenmesi amacıyla kullanılmıştır. Tartışma içeriklerinin ve öğretmen adaylarının tartışmalardaki yansıtıcı düşünme düzeyinin belirlenmesi için içerik analizi yöntemi kullanılmıştır.

İçerik analizinin önemli aşamalarından biri çözümleme biriminin seçilmesidir. Rourke, Anderson, Garrison ve Archer'a (2000) göre çözümleme biriminin seçiminde amaç farklı kodlayıcıların güvenilir ve eşzamanlı olarak tanımlayabilecekleri ve araştııılan konunun tamamıyla ortaya çıkarılmasını sağlayacak yapının belirlenmesidir. Çevrimiçi tartışmaların tam ve net bir resminin oluşturulabilmesi için uygun çözümleme biriminin belirlenmesi oldukça önemlidir. Strijbos, Martens, Prins ve Jochems (2006) çevrimiçi tartı̧maların çözümlenmesinde her 
çözümleme biriminin farklı üstün ve zayıf yönleri olduğunu belirtmişlerdir. Örneğin, kelime, mesaj gibi sabit birimler nesnel olarak tanımlanabilir olduğu halde incelenen yapının tam olarak ortaya çıkmasına uygun olmayabileceği öne sürülmektedir (Rourke ve diğerleri, 2000). Bunun yanında, "anlam birimi" gibi dinamik birimler ise tartışma belgelerinde çözümlemeye konu edilen yapıyı ortaya çıarmada daha başarılıdır. Ancak, öznel ve tutarsız birim belirleme sorunun oluşmasına neden olabilmektedir.

Tartma içerikleri ve tartışmalardaki yansıtıcı düşünme düzeyinin belirlenmesi için aynı çözümleme birimi kullanılmıştır. Çözümleme birimi seçilirken önce kolay ayrılabilir ve nesnel olarak tanımlanabilir olduğu için mesajlar çözümleme birimi olarak belirlenmiştir. Ancak çözümleme aşamasında katılımcıların aynı konudaki görüşlerini çoğu zaman ardışık mesajlar biçiminde gönderdikleri gözlemlenmiştir. Örneğin bir öğretmen adayı ilk mesajında sınıfta geçen bir olayı anlatırken, ikinci mesajında durumla ilgili görüşünü paylaşmakta üçüncü mesajında da diğer görüşleri de göz önünde bulundurarak çözüm önerisi geliştirebilmektedir. Bu örnekteki katılımın yansitıcı düşünme rubrici kullanılarak incelenmesi durumunda 1. mesaj 1 ikinci mesaj 2, üçüncü mesaj ise 5 puanla değerlendirilecektir. Bir başka anlatımla yansıtıcılık düzey $(1+2+5) / 3$ olarak bulunacaktır. Oysaki yansıtıcı düşünme araştırmalarında bireyin o konu ya da durumla ilgili çıkabildiği en yüksek yansıtıcı düşünme düzeyi temel alınır. Örneğin bu katılımcı gönderdiği üç mesajı tek bir mesaj biçiminde göndermesi durumunda yansitıcılık düzeyi 5 olarak puanlandırılır. Bu durumun ortadan kaldırılması için bu araştırmada, katılımcıların aynı konuda gönderdiği anlam bütünlüğü taşıyan mesajlar birleştirilerek anlamsal çözümleme birimi kullanılmıştır.

İlgili alanyazında yansıtıcı düşünmenin çeşitli düzeyleri olduğu kabul edilmektedir. Bu sınıflandırmalarda genellikle öğretmen adaylarının yaşanılan deneyimi anlatması en düşük düzey yansıtıcılık olarak değerlendirilirken, durumla ilgili kuramsal bakış açılarının ve alternatif davranış biçimlerinin irdelendiği yazım örnekleri de en üst düzey yansitıcilık olarak değerlendirilmektedir(Lee, 2005; Sherin ve Han, 2004). Bu çalışmada öğretmen adaylarının tartışma forumlarındaki yansıtıcılıklarının değerlendirilmesi için Manouchehri (2002) tarafından geliştirilen ve beş düzeyden oluşan yansıtıcı düşünme düzeyleri runriği kullanılmıştır. Rubrik, anlatma, açıklama, kuramsallaştırma, farklı bakış açılarının göz önünde bulundurulması ve deneyimin yeniden yapılandırılması aşamalarından oluşmaktadır (bkz. Tablo 1). 
Tablo 1. Yansitıcılık düzeyleri (Manouchehri, 2002)

\begin{tabular}{|l|l|}
\hline Düzey & Tanımı \\
\hline 1. Anlatma & Sınıfta gerçekleşen olayı yorumlamadan aktarır. \\
\hline 2. Açıklama & $\begin{array}{l}\text { Olayın olası nedenlerini ya da öğrencilerin } \\
\text { düşüncelerini tartışır. }\end{array}$ \\
\hline 3.Kuramsallaştırma & $\begin{array}{l}\text { Çözümlemesini desteklemek için araştırma } \\
\text { sonuçlarını, derste öğrendiği kuramsal bilgileri ya } \\
\text { da herhangi bir kuramsal yaklaşımı kullanır. }\end{array}$ \\
\hline $\begin{array}{l}\text { 4. Farklı bakış } \\
\text { açılarının göz } \\
\text { önünde } \\
\text { bulundurulması }\end{array}$ & $\begin{array}{l}\text { Olayın nedeniyle ilgili farklı açılamaları ve/ve ya } \\
\text { diğerlerinin görüşlerini göz önünde bulundurur. } \\
\text { Öğretimle ilgili temel varsayımları sorgulamaya } \\
\text { başlar. }\end{array}$ \\
\hline $\begin{array}{l}\text { 5. Deneyimin } \\
\text { yeniden } \\
\text { yapılandırılması }\end{array}$ & $\begin{array}{l}\text { Öğrenme etkinliğini daha iyi hale getirmek için ya } \\
\text { da olası sorunları çözmek için deneyimi yeniden } \\
\text { biçimlendirmeye odaklanır. } \\
\text { Yeniden yapılandırma ya da çözüm önerilerini } \\
\text { ortaya koyma sürecinde öne sürdüğü düşünceleri } \\
\text { kuramsallaştırması ve farklı bakış açlarını göz } \\
\text { önünde bulundurması beklenir. }\end{array}$ \\
\hline
\end{tabular}

Çözümleme birimi belirlendikten sonra, çevrimiçi tartışma metinleri araştırmacı tarafından yansıtıcı düşünme düzeylerinin ve mesaj içeriklerinin belirlenmesi amacıyla çözümlenmiştir. Çözümleme sürecinin ilk aşamasında tartışma metinleri, değindikleri konular temel alınarak gruplandırılmıştır(Sınıf Yönetimi->1, bireysel farklılıklar $\rightarrow$ 2 vb.). Bu sinıflandırma ve anlam birimlerine ayırma işlemi bittikten sonra, aynı tartışma metni yeni baştan çözümlenmiş, her bir anlam birimi değinilen içerik türüne ve yansıtıcılık puanına göre etiketlenmiştir. Daha sonra MS Excel programı kullanılarak her öğretmen adayının tartışmaya katılımı, anlamsal çözümleme birimi temel alınarak sayısallaştırılmış, her bir çözümleme biriminin içerik türü ve yansitıcılık düzeyi tablo haline getirilmiştir. Bu işlem bittikten sonra her bir içerik türü için, haftalara göre toplam katılım sayısı ve yansıtıcılık puanlarından oluşan tablo oluşturulmuştur. Oluşturulan tabloların istatistiksel incelemesi için SPSS 17 programı kullanılmıştır.

Uygulama sonunda öğretmen adaylarının çevrimiçi öğrenme ortamıyla desteklenen öğretmenlik uygulaması deneyimi ve çevrimiçi öğrenme ortamının bileşenleri hakkındaki görüşlerinin belirlenebilmesi için 8 öğretmen adayı ile yarı yapılandırılmış görüşmeler gerçekleştirilmiştir. 
Görüşme kayıtları metne dönüştürülüp içerik analizi yöntemiyle incelenmiştir.

Öğretmen adaylarına uygulanan anket sorularının belirlenmesi amacıyla görüşme verilerinin çözümlenmesinden ve alanyazın taramasından elde edilen veriler kullanılmıştır. Oluşturulan anket internet üzerinde uygulanmış ve elde edilen sonuçlar sayısallaştırılmıştır. Görüşme ve anket verileri öğretmen adaylarının öğretmenlik uygulaması döneminde yaşadıkları sorunların, hazırlanan çevrimiçi örenme ortamının bu sorunların giderilmesindeki yerinin, çevrimiçi tartışmalarda yaşanan sorunların ve bu ortamın nasıl iyileştirilebileceğinin anlaşılması amacıyla kullanılmıştır.

\section{Bulgular ve Yorum}

Çevrimiçi tartışma metinlerinin incelenmesi sonucunda öğretmen adaylarının 8 hafta süren tartı̧̧malarda toplam 472 mesaj gönderdiği belirlenmiştir. Öğretmen adayları, 178 kez mesaj başlatıcı kullanırken, 154 kez yapılandırılmış mesaj oluşturma özelliğini kullanmışlardır. Yapılan içerik analizi sonucunda 472 mesaj 340 anlam birimine ayrılmıştır.

Araştırma sorusu 1: Öğretmen adayları alan deneyimleri sürecinde çevrimiçi öğrenme ortamını nasıl kullanmaktadırlar?

$\mathrm{Bu}$ araştırma sorusu anket, yarı yapılandırılmış görüşme ve çevrimiçi tartş̧ma ortamında elde edilen veriler çözümlenerek yanıtlanmıştır. Öğretmen adaylarının \%77'si (24 öğretmen adayı) çevrimiçi tartışma forumunda, öğretmenlik uygulaması sürecinde yaşadıkları sorunları konuştuklarını ve bu durumun onları psikolojik olarak rahatlattığını öne sürmektedirler. Bu durum öğretmen adaylarıyla gerçekleştirilen görüşmelerden elde edilen verilerle desteklenmektedir. Öğretmen adayları, sınıfta yaşadıkları aksaklıkların, olumsuz öğretmen geri bildirimlerinin ve öğrenci tutumlarının kendilerini çok üzdüğünü ancak tartışma ortamında benzer sorunları yaşayan arkadaşlarıyla yaşadıkları sorunları konuşmanın kendilerini rahatlattığını, durumu normalleştirmelerine olanak sağladığını öne sürmektedirler. Örneğin öğretmen adayı 4;

"Aslında görmediğimiz açıları, benzer durumdaki arkadaşlarım neler yaşadı o durumlarda ne yaptilar benim yaptzklarım normal mi benden mi kaynaklandı? Örneğin aynı sınıfa giren başka arkadaşlarla konuşabiliyorsun onlarda yaşadıysa benzeri sorunlar demek ki sinıfla ilgili diyorsun ya da eğer sadece sen sorun yaşadiysan nedenini düşünmeye başlyyorsun. Yüz yüze bu imkan çok sinırl oluyor okula fazla gelemiyoruz kpss dersane vs. derken birçok arkadaşımız da çok az 
ders alıyor konuşma firsatı bulsak bile ayak üstü konuşuyoruz onda da çoğu zaman sıra buralara gelmiyor ya da yüzeysel kahyor."

Öğretmen adaylarının 21'i (\%68) çevrimiçi tartışma forumunu ders anlatacağı sınıflar hakkında bilgi edinmek amaciyla kullandıklarını öne sürmüşlerdir. Çevrimiçi öğrenme ortamını ders anlatacağı sınıflar hakkında bilgi almak amacıyla kullanmadığını belirten Öğretmen adaylarının oranı ise \% 19'dur (6 öğrenci). Bu bulgu Öğretmen adayları ile gerçekleştirilen görüşmelerden elde edilen verilerle desteklenmektedir. Çalışma grubunda yer alan Öğretmen adayları üst üste sadece iki hafta aynı sınıfta ders anlattıkları için çoğunlukla ders anlatacakları öğrenciler hakkında bilgi sahibi olmadan ders anlatmaya çalışmaktadırlar. Görüşme yapılan Öğretmen adaylarından 7'si öğrencilerle ilgili bu bilgi eksikliğini çevrimiçi tartışma ortamında daha önce o sınıfta ders anlatan Öğretmen adaylarıyla görüşerek giderdiklerini öne sürmüşlerdir.

"Staj sürecinde 15 öğrenciydik. Her sinıfa yalnız bir öğrenci giriyordu, iki haftalı̆̆ına o yüzden aslında sinıflar hakkında en çok bilgiyi arkadaşlarımızdan alıyorduk. Forum bu açıdan çok işimize yaradı orada gözlemlerin tartışılmasına ilişkin başlıkların yanında, sinıflar ve öğrtmenler hakkında bilgi almaya yönelik mesajlarda çok paylaşıldı, açıkçası biraz orada öğrendik hangi sinıfta neyle karşılaşacağımızı."( öğretmen adayı 2)

"Bu yöntem forum arkadaşlarımın bakış açısından da sorunlarındanda haberdar olmamı sağladı bu yönden çok faydalı oldu. Örneğin bazı arkadaşların sorunları bana fikir verdi, o sorunların çözümü için yardım aldık ya da verdik bu konuda çok yardımcı oldu."( öğretmen adayı 1)

Bir başka anlatımla, Öğretmen adayları çevrimiçi öğrenme ortamını sınıf içi olayları derinlemesine tartışarak, öğretimle ilgili varsayımlarını sorgulamaktan çok öğretmenlik uygulaması ile ilgili bilgi gereksinimlerini gidermek, süreçle ilgili dertleşmek ve psikolojik destek sağlamak amacıyla kullanmaktadırlar. $\mathrm{Bu}$ bulgu alanyazındaki araştırmalarla da desteklenmedir. Örneğin Hawkey (1995) ve McIntyre ve Tlusty (1995) öğrencilerin çevrimiçi tartışma ortamlarını, arkadaşlarıyla iletişim kurmalarına ve öğretim süreci ile ilgili duygusal destek almalarına olanak sağlayan bir araç olarak algıladıklarını belirtmektedirler.

Görüşmelerden elde edilen bir diğer sonuç, öğretmen adaylarının öğretmenlik uygulaması ya da 4. sınıftaki diğer derslerinden çok KPSS ile ilgilendikleri ve zaman planlamalarını bu sınav için yürüttükleri hazırlık çalışmalarına göre yaptıklarıdır. Yapılan görüşmelerde Öğretmen adaylarının temel kaygılarının KPSS sınavında iyi bir puan almak olduğunu, 
diğer meslekleriyle ilgili diğer uğraşlarının ancak KPSS sınavında atanmaları durumunda anlam kazanacağını belirtmişlerdir. Bir başka anlatımla, öğretmenlik eğitimlerinin son yıllarında öğretmen adaylarının temel kaygıları, ders içi ve ders dişı etkinliklerle öğretmenlik mesleği için hazır hale gelmekten çok, iş bulmaları için başarılı olmaları gereken sınavlara nasıl hazırlanacaklarıdır. Dolayısıyla, öğretmenlik uygulaması sürecinin başarımını artırmak üzere gerçekleştirilecek her türlü öğretim tasarımı bu gerçeklikten etkilenmek durumunda kalacaktır. Bu bulgu, alanyazındaki farklı araştırmalarla da desteklenmektedir. Örneğin Eraslan (2008), ilköğretim matematik öğretmen adaylarının öğretmenlik uygulaması üzerine görüşlerini belirlemek amacıyla yaptığı çalışmada öğretmenlik uygulamasının öğretmen adaylarının yoğun bir biçim KPSS için hazırlık yaptığ1 bir döneme gelmesinin, öğretmen adaylarının öğretmenlik uygulamasına yeterince zaman ayıramamalarına neden olduğunu ortaya koymuştur.

Öğretmenlerin istihdamı için yapılan KPSS nedeniyle alan deneyimlerine ve bu süreçte kullanmaları beklenen çevrimiçi öğrenme ortamına fazla zaman artırmak istememeleri Türkiye'ye özgü bir durum olsa da öğretmen adaylarının çevrimiçi tartışmalara katılım konusundaki isteksizliklerinin genel bir durum olduğu söylenebilir. Yapılan bazı araştırmalar (Hew ve Cheung, 2003; Stephens ve Hartmann, 2004), öğretmen adaylarının not gibi özendirici bir koşul olmadığında, çevrimiçi tartışmalara katılma ya da bu tartışmalarda derinlemesine görüşlerini sorgulama eğilimlerinin düşük düzeyde kaldığını göstermiştir. Bu çalışma kapsamında gerçekleştirilen yarı yapılandırılmış görüşmelerde de bu durumun altı çizilmiştir.

Araştırma Sorusu 2: Öğretmen adaylarının çevrimiçi öğrenme ortamına ve yapılandırılmış mesaj oluşturma ve mesaj başlatıcılar gibi bileşenlerine ilişkin görüşleri nelerdir?

$\mathrm{Bu}$ araştırma sorusu anket, yarı yapılandırılmış görüşme ve çevrimiçi tartışma ortamında elde edilen veriler çözümlenerek yanıtlanmıştır. Katılımcıların mesaj başlatıcılarla birlikte mesaj bölümünün üç parçaya ayrılmış olmasına ilişkin görüşleri önemli oranda benzerlik göstermektedir. Katılımcıların \% 54'ü (17 kişi), Çevrimiçi tartışma forumundaki mesaj başlatıcıları etkin olarak kullandığını düşünürken, mesaj başlatıcıları kullanmadığını belirtenlerin oranı \% 25'dir (8 kişi) (bknz. Şekil 5). Benzer bir biçimde mesaj başlatıcıların çevrimiçi tartışma forumundaki tartışmacılığın artırılmasına katkıda bulunduğunu düşünenlerin oranı \%64 (20 kişi) iken, bu görüşe katılmayanların oranı \% 9'dur (3 kişi). Çevrimiçi tartışma forumundaki mesaj başlatıcılarla ilgili öğretmen adayı görüşlerini 
sorgulamak üzere oluşturulan anket sorusunda öğretmen adaylarının \%71'i "mesaj başlatıcıların fikirlerin paylaşılmasını kısıtladığı ve tartışma kalitesini düşürdüğü" görüşünü reddetmiştir. Buna karşın bu görüşü destekleyenlerin oran1 \% 23'tür.

$\mathrm{Bu}$ sonuçlar göstermektedir $\mathrm{ki}$, katılımcların çoğunluğu mesaj başlatıcıların forum ortamındaki iletişimin tartışmacılığını artırdığını düşünmektedirler. Bu görüşle paralel olarak, katılımcıların çoğunluğu (\% 54) bu süreçte mesaj başlatıcıları kullandığını belirtmişlerdir. Ancak çevrimiçi tartışma metinleri incelendiğinde mesajların sadece \% 38'inde mesaj başlatıcı kullanıldığı görülmektedir. $\mathrm{Bu}$ durumu daha iyi anlayabilmek için öğretmen adayları ile gerçekleştirilen görüşmeler incelendiğinde, katılımcıların önemli bir kısmının mesaj başlatıcılarının ve mesajların bölümlenmesinin etkililiği konusunda hemfikir oldukları görülmektedir. Buna karşın, katılımcılar mesaj başlatıcıların bazen kendi yazım biçimlerini kısıtlayabildiğini belirtmektedirler. Örneğin Öğretmen aday 7 ;

"Ben mesela kafamda bir şey oluşturuyorum onu yazmak istiyorum ama mesaj başlatıclarla o görüşü yazmaya başlamam zor olabiliyor, ben böyle durumlarda mesaj başlatıcıları kullanmamayı tercih ediyorum"

Öğretmen adayı 8; ise

"Ben mesaj başlatıcıları pek kullanmadım açıkçası, bana uygulamak biraz zor geldi açıkçası istediğim gibi yazmak daha kolayıma geldi."

Bazı katılımcılar ise, mesaj başlatıcı sayısının sınırlı olmasının kendilerini zorladığını, öğretmen adaylarına da mesaj başlatıcı oluşturma yetkisi verilmesi gerektiğini öne sürmektedirler.

"Aslında bölümlenmiş ve başlatıcıların olması bence mesajın nedenlerini sonuçların bakış açıların ayırmak için daha faydalıydı. Mesaj başlatıcılarda bazen biraz zorluyordu yazımı ama bence daha eleştirel bakmayı sağhlıyordu. Ama bence mesaj başlatıcılara bizim de ekleme yapmamıza olanak sağlanmlıydı bence...(Öğretmen adayı, 2)"

Benzer bir biçimde öğretmen adayı 3'te mesaj başlatıcıların sayısının artırılması ve kendilerinde mesaj başlatıcı oluşturma yetkisi olmadı gerektiğini öne sürmüştür:

"Bence mesaj başlatıcı sayısı artırılmalı hatta öğretmen adayılere kendi mesaj başletıcısını ekleme olanağı sunulmalı böyle olmadığında onlar kullanmakta zorlanıyoruz. Buda bizi zorluyor açıkçası (Öğretmen adayı 5)"

Araştırmaya katılan öğretmen adaylarının \% 80'i (25 kişi) en az bir kez çevrimiçi tartışmalardaki mesajını yapılandırılmış mesaj 
oluşturma özelliğini kullanarak oluşturduğunu belirtmişlerdir. Ancak gönderilen toplam mesajların yalnızca \% 32'sinde (154 Mesaj ) bu özelliğin kullanıldığı görülmektedir. Bu bulgular ortaya koymaktadır ki, öğretmen adaylarının önemli bir kısmı mesaj yapılandırılmış mesaj oluşturma özelliğini yalnızca bazı mesajlarında kullanmışlardır. Öğretmen adaylarıyla yapılan görüşmelerin içerik analizi ile incelenmesinde elde edilen bulgular incelendiğinde bu durumun temel nedeninin yapılandırılmış mesaj oluşturma özelliğini kullanmanın zaman alması olduğu görülmektedir. Bunun dışında tartışmanın akışı içerisinde daha önce yazılan bir görüşe ilişkin yazılan yeni mesajlarda yapılandırılmış mesaj oluşturma özelliğinin kullanılmasının öğretmen adayları tarafından çok anlamlı bulunmadığı ortaya çıkmaktadır. Öğretmen adayı 2 bu duruma ilişkin görüşlerini şu şekilde dile getirmektedir:

“Bence mesaj bölümleme [yapılandırılmış mesaj oluşturma özelliği] görüşlerimizi detaylandırmak için iyi bir ortam sağlıyor, ancak bu özelliği kullanıca insan mesajın oluşturmak için daha çok düşünmek ve zaman harcamak zorunda kaliyor, bir de bazen başka bir mesajla ilişkili bir şey soracak ya da küçük bir ekleme yapacak oluyoruz. Öyle durumlarda mesaj bölümleme özelliği çok işlevsel olmuyor bence.."

Çalışmaya katılan öğretmen adayları ile gerçekleştirilen görüşmelerden elde edilen bulgulardan biri, öğretmen adaylarının çevrimiçi tartışma ortamından öğretmenlik uygulaması sürecinde yaşadıkları sorunların çözümünde kendilerine 1 şı tutabilecek kaynaklara ya da konu hakkında kendilerinden daha bilgili ve deneyimli kişilerle iletişim kurma olanağına ulaşma olanağının sağlanması gerektiğini düşündükleridir.

Araştırma bulgularından bir diğeri de öğretmen adaylarının karşılaştıkları sorunları anlamlandırmada çözüm üretmede ve ürettikleri çözümlerin doğruluğu konusunda desteğe gereksinim duyduklarıdır. Görüşme verileri incelendiğinde, öğretmen adaylarının problemle karşılaştığında, üniversitede o problemin ilgili olduğu dersi veren öğretim üyesi ile iletişim kurma gereksinimi duydukları ortaya çıkmaktadır. Bu durum farklı öğretmen adayları tarafından şu şekilde dile getirilmektedir.

"Mesela haftanin belli bir vaktinde forumda üniversiteden bir hoca olsa biz ona danışsak çok iyi olur bence. Örneğin sımıf yönetimi ile ilgili okuldaki öğretmenin bir tavrı oluyor, bu bazen bize çok yanlış geliyor. Ama emin de olamıyoruz kendi görüşümüzden, böyle durumlarda insan, o dersi aldiğı hocaya danışmak istiyor. Bu belki biraz lüks ama olsa çok iyi olabilir bence"(Öğretmen adayı 7) 
"Bence okuldaki hocalarmı bilmiyorum ne kadar mümkün ama birleşse mesela o forumdan herkese ulaşabilsek çok daha iyi olur. Yani en azından bir hoca olmalı" (Öğretmen adayı 4)

Görüşmelerden elde edilen bu bulgu ışığında oluşturulan "Çevrimiçi tartışma forumunda sınıf yönetimi, matematik öğretimi vb. alanlarda uzman olan öğretim üyelerine ulaşabilmek isterdim" cümlesine öğretmen adaylarının \%90'nın katıldığı görülmektedir.

Öğretmen adaylarının çevrimiçi tartışma forumunda bulunmasını istedikleri bir diğer katılımcı ise sınıf öğretmenleridir. Görüşme gerçekleştirilen 8 öğretmen adayından 5'i sınıf öğretmeninin tartışma ortamında bulunmasının faydalı olacağını savunmuştur. Toplam öğretmen adayları içerisinde ise bu oran \% 68' dir (21 öğretmen adayı(bknz. Şekil). Ancak öğretmen adayları bu isteklerini farklı gerekçelerle açıklamışlardır. Sınıf öğretmeninin çevrimiçi tartışma ortamında yer alması bazı öğretmen adayları tarafından ders anlatacakları sınıf hakkında bilgi alma yolu olarak görülmektedir.

"Gittiğimiz okuldaki hoca staj hocası forumda olsa o da çok iyi olur mesela her iki haftada bir yeni bir sinifa giriyoruz. Ders hazırliyoruz ama hiçbir öğrenciyi tanımadan, kimin ön bilgisi ne düzeydedir, hangi konularda iyiler, ne ilgilerini çeker kısacası hiçbir şey bilmeden yapıyoruz bunu "(Öğretmen adayı 5)

Bazı öğretmen adayları ise öğretmenlik uygulaması sürecinde ders anlatımları sonrasında öğretmenlerle yeterince vakit geçiremediklerini belirtmektedirler. Bu öğretmen adaylarına göre çevrimiçi tartışma ortamında sınıf öğretmeninin yer alması, öğretmen adaylarına ders anlatımları üzerine daha ayrıntılı konuşma olanağı sunabilir.

"Anlattığımız derslerden sonra, öğretmenle en fazla 5 dakika görüşebiliyoruz. $O$ da şansliysak, bir sürü öğrenci gelen giden derken onunda vakti olmuyor. Bu kadarlik bir zamanda öğretmen geri bildirimde bulunsa da yüzeysel kalıyor. Bence onlarda tartı̧̧malara katılsa çok daha detaylı konuşabiliriz. Bizde görüşlerimizi onlara söyleriz. Daha iyi olur yani"(Öğretmen adayı 2)

Araştırma Sorusu 3: Öğretmen adaylarının uygulama gözlemlerini tartıştıkları çevrimiçi tartışma mesajları hangi konulara odaklanmaktadır?

Araştırma sonuçlarından elde edilen bulgulardan biri çevrimiçi tartışmaların içerisinde sınıf yönetimine ilişkin konuların önemli bir yer kapladığıdır. Çevrimiçi tartışma forumundaki mesajlardan oluşan inceleme birimlerinin \% 26'sı sınıf yönetimi ile ilgili konuları kapsamaktadır (bknz. Tablo 1). Bu sonuç alanyazın tarafından da desteklenmektedir. 
Araştırmacılar mesleğe yeni başlayan öğretmenler ve öğretmen adayları için sınıf yönetiminin önemli bir sorun olduğunu ortaya koymaktadırlar (Berliner, 1988; Güven, 2004; Şahin, Şenel ve İpek, 2007).

Sınıf yönetiminden sonra çevrimiçi tartışmalara en çok konu olan alan öğretim sürecidir(\%14). Bu alanı \%13 ile öğretmenlik mesleğiyle ilgili genel konular izlemektedir. Çevrimiçi tartışma forumunda paylaşılan ve öğretmenlik uygulaması ile ilişkisi bulunmayan inceleme birimlerinin oranı ise \% 12'dir. Bu sonuçlar incelendiğinde öğretmen adaylarının toplam iletişiminin ancak \% 14 gibi küçük bir kısmının öğretim süreci ile ilgili olduğu görülebilir. Bu bulgu alanyazındaki diğer araştırmalarla da desteklenmektedir. Araştırmalar göstermektedir ki, öğretmen adayları çevrimiçi tartışma ortamlarını yaşadıkları öğretim deneyimi üzerine yansitıcı düşünmek yerine ortaya çıkan gündelik sorunlarla ilgili iletişim kurmak amacıyla kullanmaktadırlar.

Tablo 1. Çözümleme Birimlerinin Konulara ve Haftalara Göre Dağılımı

\begin{tabular}{|c|c|c|c|c|c|c|c|c|c|}
\hline Konular & 1. Hafta & 2. Hafta & 3. Hafta & 4. Hafta & 5. Hafta & 6. Hafta & 7. Hafta & 8. Hafta & Toplam \\
\hline Öğretim Süreci & 7 & 3 & 2 & 10 & 8 & 0 & 11 & 8 & 49 \\
\hline $\begin{array}{l}\text { Sinif Yönetimi } \\
\text { (ögrrenci- } \\
\text { ögretmen } \\
\text { iletişimi, } \\
\text { ögretmen }\end{array}$ & & & & & & & & & \\
\hline $\begin{array}{l}\text { tutumları) } \\
\text { Öğrenci }\end{array}$ & 35 & 9 & 26 & 7 & 0 & 4 & 5 & 3 & 89 \\
\hline $\begin{array}{l}\text { Değerlendirmesi } \\
\text { Özyeterlik }\end{array}$ & 1 & 1 & & 1 & 5 & 3 & 3 & 3 & 17 \\
\hline Algıları & 2 & 1 & & 1 & 0 & 0 & 0 & 0 & 4 \\
\hline $\begin{array}{l}\text { Duygusal Boyut } \\
\text { Bireysel }\end{array}$ & 0 & 0 & 3 & 5 & 4 & 7 & 7 & 6 & 32 \\
\hline $\begin{array}{l}\text { Farklılıklar } \\
\text { Öğretmenlik } \\
\text { Mesleğine } \\
\text { İlişkin Genel }\end{array}$ & 0 & 5 & 2 & 4 & 0 & 0 & 8 & 5 & 24 \\
\hline Konular & 0 & 6 & 5 & 4 & 2 & 7 & 11 & 8 & 43 \\
\hline $\begin{array}{l}\text { İdari } \\
\text { Öretmen Adayı- } \\
\text { Uygulama } \\
\text { Öğretmeni }\end{array}$ & 0 & 0 & 10 & 3 & 0 & 0 & 3 & 3 & 19 \\
\hline İletişimi & 3 & 10 & 2 & 0 & 0 & 7 & 0 & 0 & 22 \\
\hline Diğer Konular & 3 & & 6 & 4 & 2 & 7 & 6 & 13 & 41 \\
\hline
\end{tabular}

Araştırma bulguları incelendiğinde ortaya çıan şaşırtıcı sonuçlardan biri öğretmen adaylarının, alanyazındaki bulguların aksine, çevrimiçi tartışmalarda dersin planlanması süreci ile ilgili hiçbir tartışma 
üretmemiş olmalarıdır. Bu durumun nedeni, öğretmen adaylarının hazır planlar kullanmaları olabilir.

Araştırma Sorusu 4: Uygulama sürecinde öğretmen adaylarının sınıf gözlemlerine ilişkin yansıtıcılıklarında bir artış gözlemlenmekte midir?

Çevrimiçi öğrenme ortamı ile desteklenen alan deneyimi sürecinde öğretmen adaylarının yansıtıcı düşünme düzeylerinde bir farklılık olup olmadığının anlaşılabilmesi için öğretmen adaylarının uygulamanın ilk iki haftasındaki çevrimiçi tartışma forumundaki mesajlarının yansıtıcılık düzeyleri (öntest), son iki haftadaki çevrimiçi tartışma forumundaki mesajlarının yansıtıcılık düzeyleri(sontest) ile karşılaştırılmıştır.

Verilerin normallik varsayımlarını karşılayıp karşılamadığının belirlenebilmesi için SPSS 17 programı kullanılarak kolmogrov-smirnov testi uygulanmıştır. Test sonuçlarının verilerin normallik varsayımlarını karşıladığını göstermesi üzerine eşleştirilmiş örneklem t-testi kullanılarak ilk iki hafta- son iki hafta yansıtıcılık düzeyleri karşılaştırılmıştır.

Tablo 2. Yansıtıcılık Puanlarının Karşılaştırılmasına İlişkin t-testi Sonuçları

\begin{tabular}{lllllll}
\hline Ölçüm & $\mathrm{N}$ & $\mathrm{X}$ & $\mathrm{SS}$ & $\mathrm{Sd}$ & $\mathrm{t}$ & $\mathrm{P}$ \\
\hline Öntest & 31 & 2.38 & 0.90 & \multirow{2}{*}{31} & 4.73 & .000 \\
Sontest & 31 & 3.02 & 0.88 & & & \\
\hline
\end{tabular}

Yapılan t-testi sonucunda öğretmen adaylarının son iki hafta mesajlarının yansitıcılık düzeylerinin $(X=3.02)$ ilk iki haftaki mesajlarının yansitıcılık düzeylerinden $(X=2.38)$ anlamlı biçimde yüksek olduğu görülmüştür (bknz. Tablo 2). Buradan yola çıkarak çevrimiçi tartışma ortamı ile desteklenen öğretmenlik uygulaması sürecinde öğretmen adaylarının yansıtıcılık düzeylerin arttığı söylenebilir.

Alanyazın da alan deneyimi sürecinin yansıtıcı düşünme düzeyine etkisi ve çevrimiçi tartışmalarla desteklenen durum çalışmalarının yansıtıcı düşünmeye etkisi ile ilgili çalışmalar bulmak mümkündür. Ancak bu araştırmada kullanılan çevrimiçi öğrenme ortamına benzer özellikler taşıyan bir ortamla alan deneyimi sürecinin desteklenmesine ilişkin bir çalışmaya rastlanılamamıştır. Dolayısıyla sonuçların önceki çalışmalarla kıyaslanması güçtür. Bunun yanında, bu araştırmada tam deneysel bir model kullanılmamıştır. Dolaysıyla öğretmen adaylarının yansitıcı düşünme düzeylerindeki artış uygulama dişında olgunlaşma etkisine ya da bu süreçte yaşadıkları diğer deneyimlere ya da aldıkları diğer derslere bağlı olabilir. Sonuçlar yorumlanırken bu durum göz önünde bulundurulmalıdır. 


\section{Sonuç ve Öneriler}

$\mathrm{Bu}$ araştırmanın ortaya koyduğu sonuçlardan biri, öğretmen adaylarının alan deneyimi sürecinde, sürecin diğer paydaşları olan uygulama öğretmeni, dersle ilgili öğretim elemanı ve üniversitedeki diğer öğretim elemanlarıyla iletişim kurma gereksinimi duydukları ancak bu gereksinimin yeterince karşılanamadığıdır. Öğretmen adayları bu süreçte uygulama öğretmeninden dönüt verme için daha fazla zaman ayırmasını ve daha ayrıntılı dönüt vermesini beklemektedir. Dersin planlanması ve öğretmen adayının anlatacağı konunun belirlenmesi öğretmen adaylarının uygulama öğretmeni ile iletişim kurmak istedikleri bir diğer konudur. Çevrimiçi iletişim ortamının öğretmen adayı-uygulama öğretmeni iletişimini kurmada sürece katkı sağlaması olasıdır. Ancak, öğretmen adaylarının uygulamaları nesnel olarak değerlendirebilmeleri ve deneyimleri üzerine özgür bir ortamda yansıtmada bulunabilmeleri için bu çalışmada çevrimiçi tartışma ortamına uygulama öğretmenleri dahil edilmemiştir.

Öğretmen adaylarının daha fazla iletişim kurma gereksinimi hissettiği bir diğer aktör, dersle ilgili uygulama öğretim elemanıdır. Öğretmen adayları, öğretmenlik uygulaması sürecince karşılaştıkları bütün sorunlarda ilk olarak ilgili öğretim elemanı ile iletişim kurmak istemektedirler. Bu çalışma kapsamında çevrimiçi tartışma ortamına dersle ilgili öğretim üyesinin katılımı sağlanmıştır. Ancak çevrimiçi tartışma ortamının eş zamansız yapısı öğretmen adaylarının gereksinim duydukları danışmanlığı gereksinim duydukları anda alamamalarına neden olmuş olabilir. Bu durumun giderilebilmesi için dersin öğretim elemanı ile öğretmen adaylarının eş-zamanlı çevrimiçi tartışma ortamı bileşenleri üzerinden iletişim kurmalara sağlanabilir.

Öğretmen adayları sınıf yönetimi, öğretim etkinlikleri gibi alanlarda herhangi bir sorun yaşadıklarında, konu ile ilgili ders aldıkları öğretim üyesine danışma gereksinimi duymaktadırlar. Ancak var olan düzenlemelere göre bu durumun sağlanması oldukça güçtür.

$\mathrm{Bu}$ araştırmanın ortaya koyduğu bir diğer sonuç, öğretmenlik uygulaması dersi için tasarlanmış olan çevrimiçi tartışma ortamının öğretmen adayları tarafından yararlı olarak algılandığıdır. Öğretmen adaylarına göre çevrimiçi tartışma ortamının kendilerine sağladıkları olanaklardan biri öğretmenlik uygulamasında yaşanan sorunları paylaşarak diğer öğretmen adaylarından psikolojik ve duygusal destek almalarına olanak sağlamasıdır. Bunun yanında öğretmenlik uygulamasında öğretim gerçekleştirilecek sınıf hakkında daha önce o sınıfta öğretim gerçekleştiren öğretmen adaylarından bilgi alma olanağı sunması, öretmen adayları 
tarafından çevrimiçi tartışma ortamının kendilerine sağladığı önemli bir olanak olarak algılanmaktadır. Öğretmen adaylarına göre çevrimiçi tartışma ortamının öğretmenlik uygulaması sürecine bir diğer katkısı, öğretimle ilgili görüşlerini tartışma, farklı görüşlerden haberdar olma olanağı sunmasıdır. Kısacası, çevrimiçi tartışma ortamı öğretmen adayları tarafından yansıtıcı düşünmek için bir araç olmanın ötesinde süreçte yaşanan sorunlarla ilgili destek almak, bilgi toplamak ve farklı görüşlerden haberdar olmaya olanak sağlayan bir iletişim ortamı olarak algılanmaktadır.

$\mathrm{Bu}$ çalışmada elde edilen bir diğer sonuç, öğretmen adaylarının deneyimlerini eleştirel ve tartışmacı bir biçimde değerlendirmesine olanak sağlamak amacıyla çevrimiçi tartışma ortamının yapılandırılmasında kullanılan mesaj başlatıcıların öğretmen adayları tarafından görüşleri daha tartışmacı biçimde incelemelerine katkı sağlayan bir araç olarak algılandığıdır. Bununla birlikte, öğretmen adayları sınırlı sayıdaki mesaj başlatıcıların yazımlarını zorlaştırdığını ve sınırlandırdığını belirtmektedirler. Bir başka anlatımla mesaj başlatıcılar, mesajların tartışmacılığını artıran ancak daha fazla zaman ve çaba harcanmasına neden olan yapılandırma araçları olarak algılanmaktadır.

Çevrimiçi tartışma forumunda paylaşılan mesajlarda değinilen konular içerik bakımından incelendiğinde en çok sınıf yönetimi ile ilgili konuların tartışıldığı görülmektedir. Öğretmen adaylarının ve mesleğe yeni başlayan öğretmenlerin en çok sinıf yönetimi ile ilgili konularda sorun yaşadıkları alanyazında da oldukça sık rastlanan bir bulgudur (Şahin, Şenel ve İpek, 2007; Güven, 2004).

Öğretmen adaylarının deneyimlerine ilişkin mesajlarının yansıtıcılık düzeyleri bakımından incelendiğinde, uygulama süreci sonunda yansıtıcılık düzeylerinin anlamlı oranda arttı̆̆1 görülmektedir. Ancak araştırmada herhangi bir kontrol grubu kullanılmadığı için bu etkinin doğrudan yapılandırılmış çevrimiçi tartışma forumu ile gerçekleştirilen uygulamadan kaynaklandığı öne sürülemez.

$\mathrm{Bu}$ araştırmanın sonuçları yorumlanırken, araştırmanın sınırlılıklarını göz önünde bulundurmak doğru bir yaklaşım olacaktır. Bu sınırlılıklardan ilki çalışmada kontrol grubu kullanılmamış olmasıdır. Bir diğer sınırlılık çalışmaya katılan öğretmen adaylarının önemli bir kısmının internet erişimlerinin olmamasıdır. Bu durum öğretmen adaylarının gereksinim duyduklarında yapılandırılmış tartışma forumuna katılmalarını etkilemiş olabilir. Ayrıca ülkemizde uygulanan KPSS sınavı öğretmen adayları üzerinde büyük bir zaman baskısı yaratmakta ve öncelik sıralamalarını değiştirmektedir. Dolayısıyla araştırma bulgularının uluslararası düzeyde yorumlanmasında bu durumun dikkate alınması 
gerekmektedir. Türkiye'de uygulanan öğretmenlik uygulamasında öğretmen adaylarının haftanın yalnızca bir gününde uygulama okulunda bulunmaktadırlar. Dolayısıyla, öğretmenlik uygulaması süreci daha dağınıktır. Bu durumun da araştırma sonuçlarının uluslararası düzeyde yorumlanmasını etkileyebilecek bir diğer konu olduğu öne sürülebilir.

Bu sonuçlar ışığında uygulama için getirilebilecek öneriler:

1. Uygulama öğretmeni, öğretim üyesi ve öğretmen adayı iletişiminin geliştirilmesi için eş zamanlı ve eş zamansız çevrimiçi iletişim olanakları harmanlanabilir.

2. Çevrimiçi tartışma forumunda belirli zamanlarda sınıf yönetimi, özel öğretim yöntemleri vb. alanlarda uzmanlar davet edilerek öğretmen adaylarının uygulama sürecinde karşılaştıkları sorunlar konusunda yardım almaları sağlanabilir.

3. Çevrimiçi tartışma ortamına öğretmen rehber kitabı, diğer öğretmen adaylarının ders planları, farklı etkinlikler üretmede kullanabilecekleri kaynaklar eklenebilir.

4. Öğretmen adaylarının mesaj başlatıcı oluşturmalarına olanak sağlanabilir. Böylece öğretmen adaylarının görüşlerini daha rahat dile getirmelerine olanak sağlarken mesaj başlatıcıların kullanılma oranı da artırılabilir.

Bu sonuçlar ışığında araştırmalar için getirilebilecek öneriler:

1. Benzeri çalışmalar kontrol gruplu deneysel desende tasarlanarak çevrimiçi tartışma ortamı ile ve mesaj başlatıcılarla yapılandırılmış çevrimiçi tartışma ortamının öğretmen adaylarının yansitıcılık düzeylerine etkisi araştırılabilir.

2. $\mathrm{Bu}$ araştırmada ve alanyazındaki pek çok araştırmada çevrimiçi tartışma forumu kullanımı incelenilirken zaman boyutu araştırma dışında tutulmaktadır. Öğretmen adaylarının, öğretmenlik uygulaması sürecinde yansıtıcılıklarının ve çevrimiçi tartışma ortamı kullanımlarının zamana dayalı çözümlenmesi uygulamacı ve araştırmacılara 1şık tutabilir. 


\section{Kaynaklar}

ABELL, S.K. , Dillon, D.R., Hopkins, C.J. , McInerney, W.D. \& O’Brien, D.G. (1995). Somebody to count on: mentor/intern relationships in a beginning teacher internship program, Teaching and Teacher Education 11 (2), 173-188

ARREDONDO, D.E. \& Rucinski, T.T. (1998). Using structured interactions in conferences and journals to promote cognitive development among mentors and mentees. Journal of Curriculum and Supervision, 13(4), 300-327.

BARONE, T., Berliner, D. C., Blanchard, J., Casanova, U., \& McGowan, T. (1996). A future for teacher education. In J. Siluka (Ed.), Handbook of research on teacher education (pp. 1108-1149). New York: Macmillan.

BENCZE, L., Hewitt, J., \& Pedretti, E. ( 2001). Multi-media case methods in pre-service science education: Enabling an apprenticeship for praxis. Science Education, 31, 191-209.

BERLINER, D. C. (1988). Implications of studies on expertise in pedagogy for teacher education and evaluation. In New directions for teacher assessment. (Proceedings of the 1988 ETS International Conference, pp. 39 - 68). Princeton, NJ: Educational Testing Service.

BORKO, H. \& Mayfield, V. (1995). The roles of the cooperating teacher and university supervisor in learning to teach. Teaching $\&$ Teacher Education ${ }_{\mathrm{L}}$ 11, 501-518.

CRESWELL, J.\& Clark, V. (2007) Designing and Conducting Mixed Methods Research. Thousand Oaks CA: Sage

COCHRAN-SMITH, M, \& Lytle, S. (1993). Insideloutside: Teacher research and knowledge. New York, NY: Teachers College Press.

DE WEVER, B., Schellens, T., Valcke, M., \& Van Keer, H. (2006). Content analysis schemes to analyze transcripts of online asynchronous discussion groups: A review. Computers $\mathcal{E}$ Education, 46, 6-28.

ERARSLAN, A. (2008). Fakülte-okul işbirliği programı: matematik öğretmeni adaylarının okul uygulama dersi üzerine görüşleri. Hacettepe Üniversitesi Ĕ̆itim Fakültesi Dergisi, 34, 95-105.

FEIMAM-NEMSER, S., \& Buchman, M. (1985). Pitfalls of experience in teacher preparation. Teachers College Record, 87(1), 53-65.

GÖKÇE, E. \& Demirhan, C. (2005). Öğretmen adaylarının ve ilköğretim okullarında görev yapan uygulama öğretmenlerinin öğretmenlik uygulaması etkinliklerine ilişkin görüşleri. Ankara Üniversitesi ğitim Bilimleri Fakültesi Dergisi. 38(1): 43-71. 
GÜVEN, İ. (2004). Sosyal Bilgiler Alanı Öğretmen Adaylarının Okul Uygulamalarına Yönelik Görüşlerine İlişkin Nitel Bir Araştırma, Kuramdan Uygulamaya Eğitim Bilimleri Dergisi, 4/2.

HAWKEY, K. (1995). Learning from peers: The experience of student teachers in school-based teacher education. Journal of Teacher Education, 46, 175-183.

HEW, K. F. \& Cheung, W. S. (2003). Models to evaluate online learning communities of asynchronous discussion forums. Australian Journal of Educational Technology, 19(2), 241-259.

HEW, K. F., Cheung, W. S., \& Ling, C. S. (2009). Student contribution in asynchronous online discussion: A review of the research and empirical exploration. Instructional Sience. Online first.

KIRAZ, E. (2002). Öğretmen adaylarının hizmet öncesi mesleki gelişiminde uygulama öğretmenlerinin işlevi. Eğitim Bilimleri ve Uygulama, 2(1), 183-196.

LAMPERT, M., \& Ball, D. (July 1990). Using hypermedia technology to support a new pedagogy of teacher education. National Center for Research on Teacher Education, Michigan State University.

LAPADAT, J. S. (2002). Written interaction: a key component in online learning. Journal of Computer Mediated Communication. 7 Ocak 2012 tarihinde ulaşıldı. www.ascusc.org/jcmc/vol7/issue4/lapadat.html.

LEE, H. J. (2005). Understanding and assessing preservice teachers' reflective thinking. Teaching and teacher education, 21(6), 699-715.

LORTIE, S. (1975). Schoolteacher: A sociological study. Chicago: University of Chicago Press.

MANOUCHEHRI, A. (2002). Developing teaching knowledge through peer discourse. Teaching and Teacher Education, 18(6), 715-737.

MCINTYRE, S. R., \& Tlusty, R. H.( 1995.) Computer-Mediated Discourse. Presented at the American Educational Research Association conference, (ED 385 232)

ÖZBEK, T. Z., ve Aytekin, F. (2003). Eğitim fakültesi öğrencilerin öğretmenlik mesleğine bakış açları ve öğretmenlik uygulaması dersinde memnuniyet durumları üzerinde bir araştırma. Çağdaş Ĕ̆itim Dergisi, 284(2), 31-39.

PAKER, T. (2005, Eylül). Öğretmenlik uygulamasında öğretmen adaylarının uygulama öğretmeni ve uygulama öğretim elemanının yönlendirmesiyle ilgili karşılaştıkları sorunlar. XIV. Ulusal Eğitim Bilimleri Kongresinde sunulan bildiri.

PINCAS, A. (1995, Temmuz). Why computer conferencing may help students more than face-to-face teaching, Altıncı Cambridge International 
Conference on Open and Distance Learning konferansında sunulan bildiri. 20 Mayıs 2009 tarihinde ulaşıldı, http://icdllit.open.ac.uk/icdlbrowse1.php?a=00009317

ROURKE, L., Anderson, T., Garrison, D. R., \& Archer, W. (2001). Methodological issues in the content analysis of computer conference transcripts. International Journal of Artificial Intelligence in Education, 12, 8-22.

ROMISZOWSKI, A., \& Mason, R. (2004). Computer-mediated communication. In D. H. Jonassen. (Ed.), Handbook of research for educational communications and technology (pp. 397-431). (2nd ed.). New York: Simon \& Schuster Macmillan.

SANTAGATA, R., Zannoni, C., \& Stigler, J. (2007). The role of lesson analysis in pre-service teacher education: An empirical investigation of teacher learning from a virtual video-based field experience. Journal of Mathematics Teacher Education. 10(2), 123-140.

SCHUNK, D. H. (2004). Learning theories: an educational perspective (4th Ed.).Upper Saddle River, NJ: Pearson Prentice Hall.

SHERIN, M. G., \& Han, S. Y. (2004). Teacher learning in the context of a video club. Teaching and Teacher Education, 20(2), 163-183.

STEPHENS, A. C. \& Hartmann, C. E. (2004). A successful professional development project's failure to promote online discussion about teaching mathematics with technology. Journal of Technology and Teacher Education, 12(1), 57-73.

STRIJBOS, J. W., Martens, R. L., Prins, F. J., \& Jochems, W. M. G. (2006) Content analysis: What are they talking about? Computers and Education, 46, 29-48.

SWAN, K. (2002). Building communities in online courses: the importance of interaction. Education, Communication and Information, 2 (1), 23-49.

ŞAHIN. Ç., Şenel, T. \& İpek, H. (2007, Eylül). Öğretmen Adaylarının Öğretmenlik Uygulamalarında Karşılaştıkları Problemlerin Belirlenmesi. XVI Ulusal Eğitim Bilimleri Kongresi, Gaziosmanpaşa Üniversitesi Eğitim Fakültesi, Tokat.

TANG S. Y. F. (2003). Challenge and support: thedynamics of student teachers' Professional learning in the field experience. Teaching and Teacher Education, 19, 483-498

WANG, S. K. (2008). The effects of a synchronous communication tool (yahoo messenger) on online learners' sense of community and their multimedia authoring skills. Journal of Interactive Online Learning, $7(1), 59-74$. 
YAMADA, M. (2009). The role of social presence in learner-centered communicative language learning using synchronous computermediated communication: experimental study. Computers $\mathcal{E}$ Education, 52, 820-833.

YILDIZ, E (2002). Okul Deneyimi I ve okul Deneyimi II derslerinin değerlendirilmesi. Yayınlanmış yüksek lisans tezi. Sakarya: Sakarya Üniversitesi

YODKAMLUE, B. (2008). Online texts of non-native speakers in an L2 electronic discussion forum: an analysis of social presence and cognitive presence. Yayınlanmamış doktora tezi. University of South Carilona.

YÜKSEKÖĞRETIM KURULU. (1998). YÖK Dünya Bankası Fakülte-Okul İşbirliği Kılavuzu. Ankara: Öğretmen Eğitimi Dizisi.

ZEICHNER, K., \& Tabachnick, R. (1981). Are the effects of university teacher education washed out by school experience? Journal of Teacher Education, 32(3),3-11. 
H. ÖZÇINAR | 202 